\title{
Graphical aids for visualizing Byram's fireline intensity in relation to flame length and crown scorch height
}

\author{
by Martin E. Alexander ${ }^{1}$ and Miguel G. Cruz ${ }^{2}$
}

\begin{abstract}
Summary graphs depicting 20 individual flame length-fire intensity relationships grouped by four different fuel complex types or settings (forest, grassland, shrubland, and laboratory) and 12 individual fireline intensity-crown scorch height relationships for two broad forest stand types (conifer- and eucalypt-dominated) are presented. Users will find these quick reference visual aids of value in a wide variety of fire management applications.
\end{abstract}

Key words: crown fire, fire behaviour, fire impact, fire management, fire suppression, flame dimensions, prescribed fire, surface fire, wildland fire

\section{RÉSUMÉ}

Cet article présente des graphiques récapitulatifs décrivant 20 relations indépendantes entre la hauteur des flammes et l'intensité du feu regroupées selon quatre différents types de combustibles ou denvironnements (forêt, prairie sèche, prairie boisée et laboratoire) et 12 relations entre limportance du coupe feu et la hauteur des cimes brûlées pour deux grands types de peuplement (à dominance de conifères ou deucalyptus). Ces guides visuels et rapides à consulter seront d'une grande valeur pour les utilisateurs dans un grand nombre de situations de contrôle de feux.

Mots clés : feu de cime, comportement du feu, impact du feu, contrôle des feux, extinction des feux, dimensions des flammes, brûlage dirigé, feu de surface, feu hors contrôle

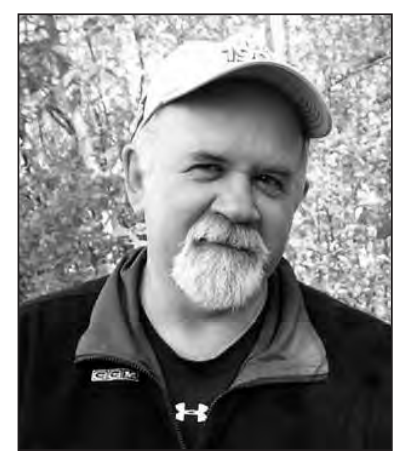

Martin E. Alexander

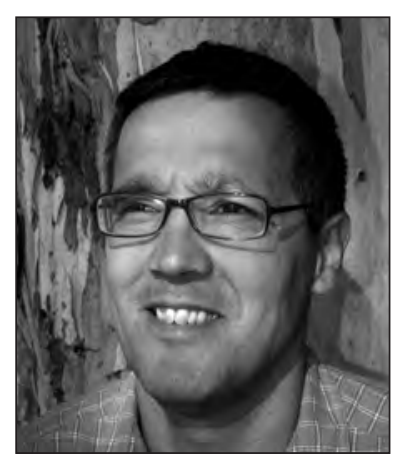

Miguel G. Cruz

\section{Introduction}

We recently published a review article examining the interrelationships amongst four widely used descriptors of surface fire behaviour (Fig. 1) and post-fire impacts in wildland fire science and management (Alexander and Cruz 2012a); namely, fireline intensity, flame length, stem-bark char height, and crown scorch height-terms that should be part and parcel of a forester's lexicon (Beck et al. 2005). This note will serve to compliment that effort by offering graphical representations of the flame length-fireline intensity and fireline intensity-crown scorch height relationships as listed in Alexander and Cruz (2012a,b). Users will find the graphical aids presented here of value in support of a wide variety fire management decision-making activities.

\section{Flame Length-Fireline Intensity Relationships}

Byram (1959) defined fireline intensity as the rate of heat energy release per unit time per unit length of fire front, regardless of the depth or width of the zone of active flaming combustion (Alexander 1982). The formula to compute fireline intensity is as follows:

$$
\text { [1] } I_{B}=H \cdot w_{a} \cdot r
$$

where $I_{B}$ is Byram's fireline intensity $(\mathrm{kW} / \mathrm{m}), H$ is the net low heat of combustion $(\mathrm{kJ} / \mathrm{kg}), w_{a}$ is the fuel consumed in the active flame front $\left(\mathrm{kg} / \mathrm{m}^{2}\right)$, and $r$ is the linear rate of fire $\operatorname{spread}(\mathrm{m} / \mathrm{sec})$.

Byram (1959) derived the following relationship based on observations of flame length $(L, \mathrm{~m})$ (Fig. 2a) and computations of $I_{B}$ using eq. [1] and measurements of $w_{a}$ and $r$ coupled with an assumed value for $H$ (from Alexander 1982):

$$
\text { [2] } L=0.0775 \cdot I_{B}^{0.46}
$$

A list of 19 other $L-I_{B}$ equations or models is presented in Alexander and Cruz (2012b). The experimental data range in the variables associated with these equations is given in Alexander and Cruz (2012a). The graph represented by Fig. 3 has now in turn been produced from the equation list. The variation evident in Fig. 3 is due in large part to differences in fuel complex structure and type of fire as well as the measurement methodologies as discussed by Alexander and Cruz (2012a).

\footnotetext{
${ }^{1}$ R.P.F., Adjunct Professor of Wildland Fire Science and Management, University of Alberta, Department of Renewable Resources and Alberta School of Forest Science and Management, Edmonton, Alberta T6G 2H1. Corresponding author. E-mail: mea2@telus.net ${ }^{2}$ Senior Research Scientist, Bushfire Dynamics and Applications Team, CSIRO Ecosystem Sciences and Climate Adaptation Flagship, GPO Box 1700, Canberra, ACT 2601, Australia.
} 


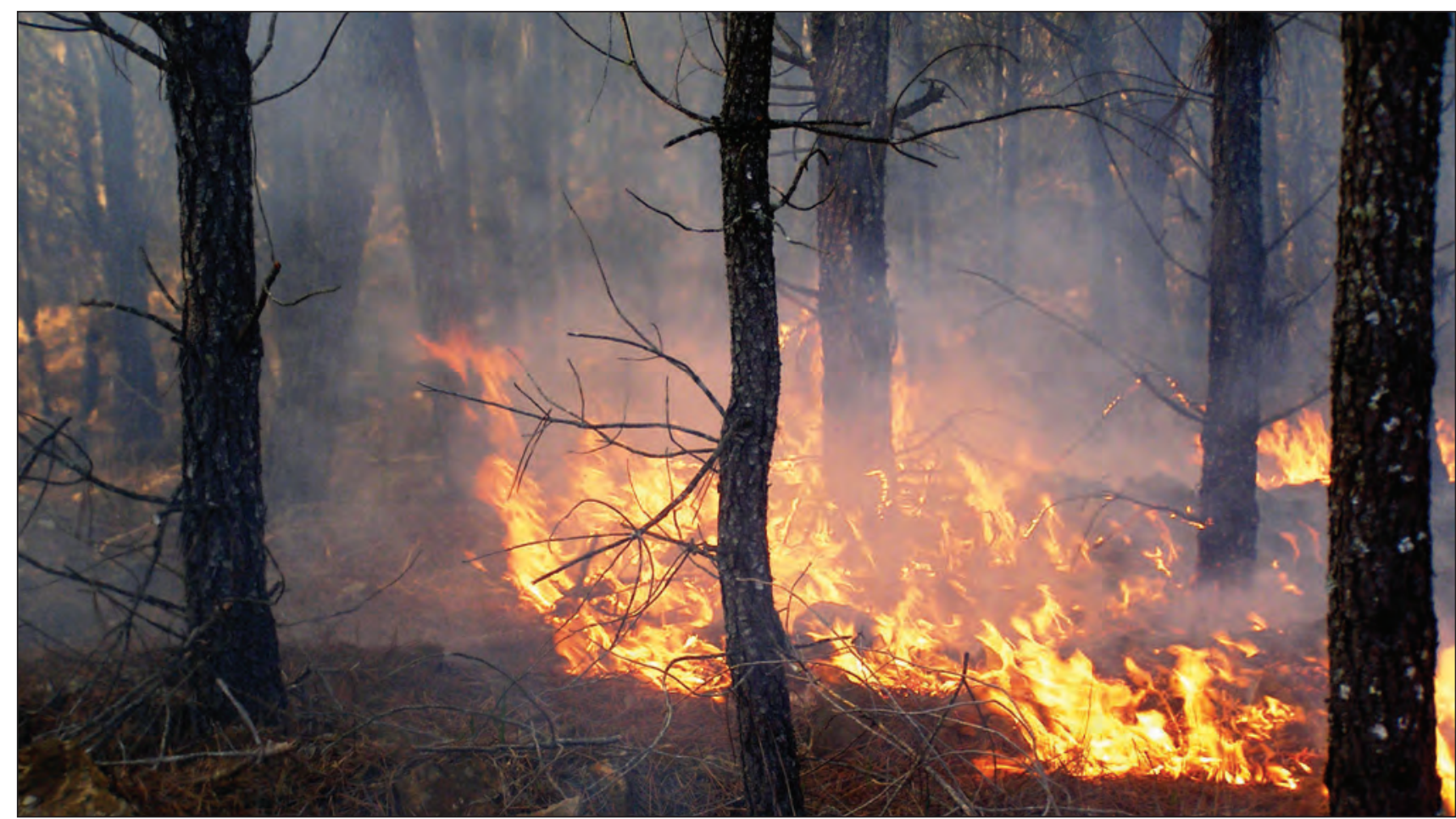

Fig. 1. Surface heading fire in a 15-year-old unthinned and unpruned maritime pine (Pinus pinaster Aiton) plantation (2 $\times 1 \mathrm{~m}$ spacing) in the Viseu region of central Portugal on February 1, 2007. Dominant trees are $12 \mathrm{~m}$ in height with a diameter-at-breast height of $15 \mathrm{~cm}$. Photo by Paulo M. Fernandes, Universidade de Trás-os-Montes e Alto Douro, Vila Real, Portugal.

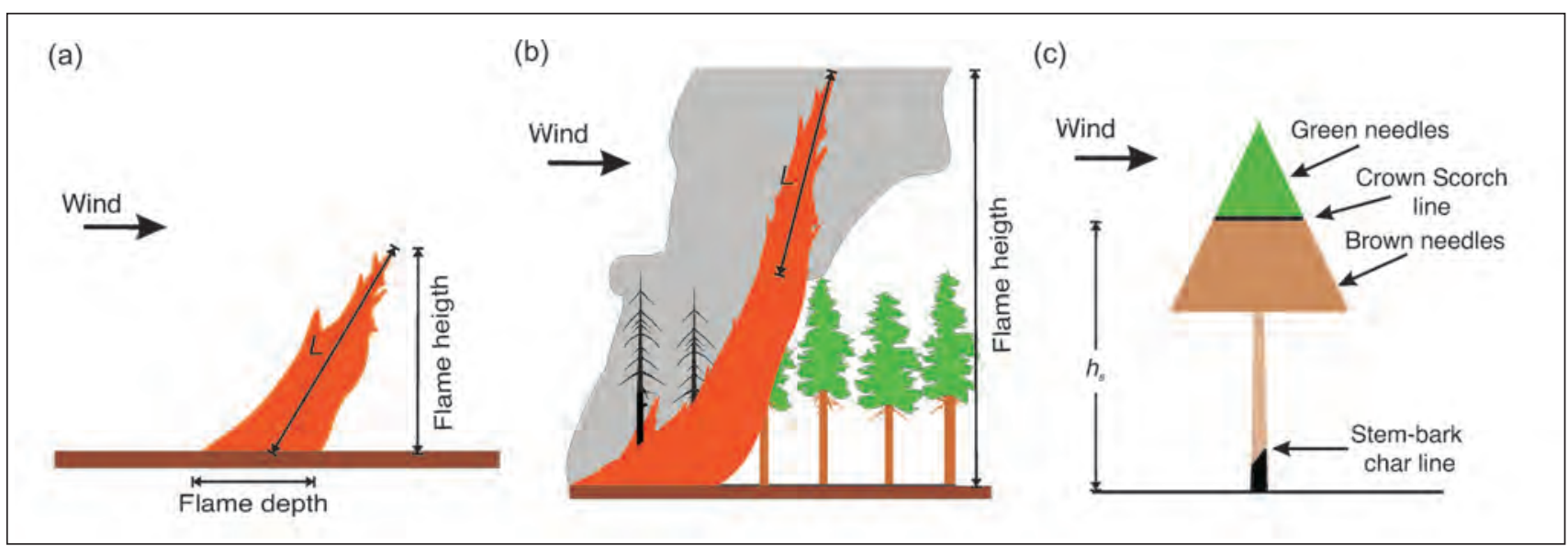

Fig. 2. Schematic diagram illustrating the flame length $(L)$ dimension of a wind-aided (a) surface fire and (b) crown fire on level terrain and (c) crown scorch height $\left(h_{s}\right)$ in the overstorey tree canopy resulting from the upward heating by the flames following passage of the advancing flame front. Flame length and flame height are equivalent in the case of no wind and no slope.

\section{Fireline Intensity-Crown Scorch Height Relationships} Above any forest fire burning on the ground surface, providing it is sufficiently intense and the live overstory canopy is not too high, there will be a height to which the tree foliage will be scorched by hot gases rising upwards from the flames (Byram 1958). Van Wagner (1973) was the first to formally link crown scorch height $\left(h_{s}, \mathrm{~m}\right)$ (Fig. 2c) to $I_{B}$ based on a series of experimental fires carried out at the former Petawawa Forest Experiment Station near Chalk River, Ontario (from Alexander 1982):

$$
\text { [3] } h_{s}=0.1483 \cdot I_{B}^{0.667}
$$

Taking the inverse or reciprocal of equation [3] allows one to estimate $I_{B}$ from $h_{s}$ (from Alexander and Cruz 2012a):

$$
\text { [4] } I_{B}=17.49 \cdot h_{s}^{1.5}
$$

A list of 11 other $I_{B}-h_{S}$ equations or models, including the experimental data range in the variables associated with these equations, is presented in Alexander and Cruz (2012a). The graph represented by Fig. 4 has now in turn been produced 

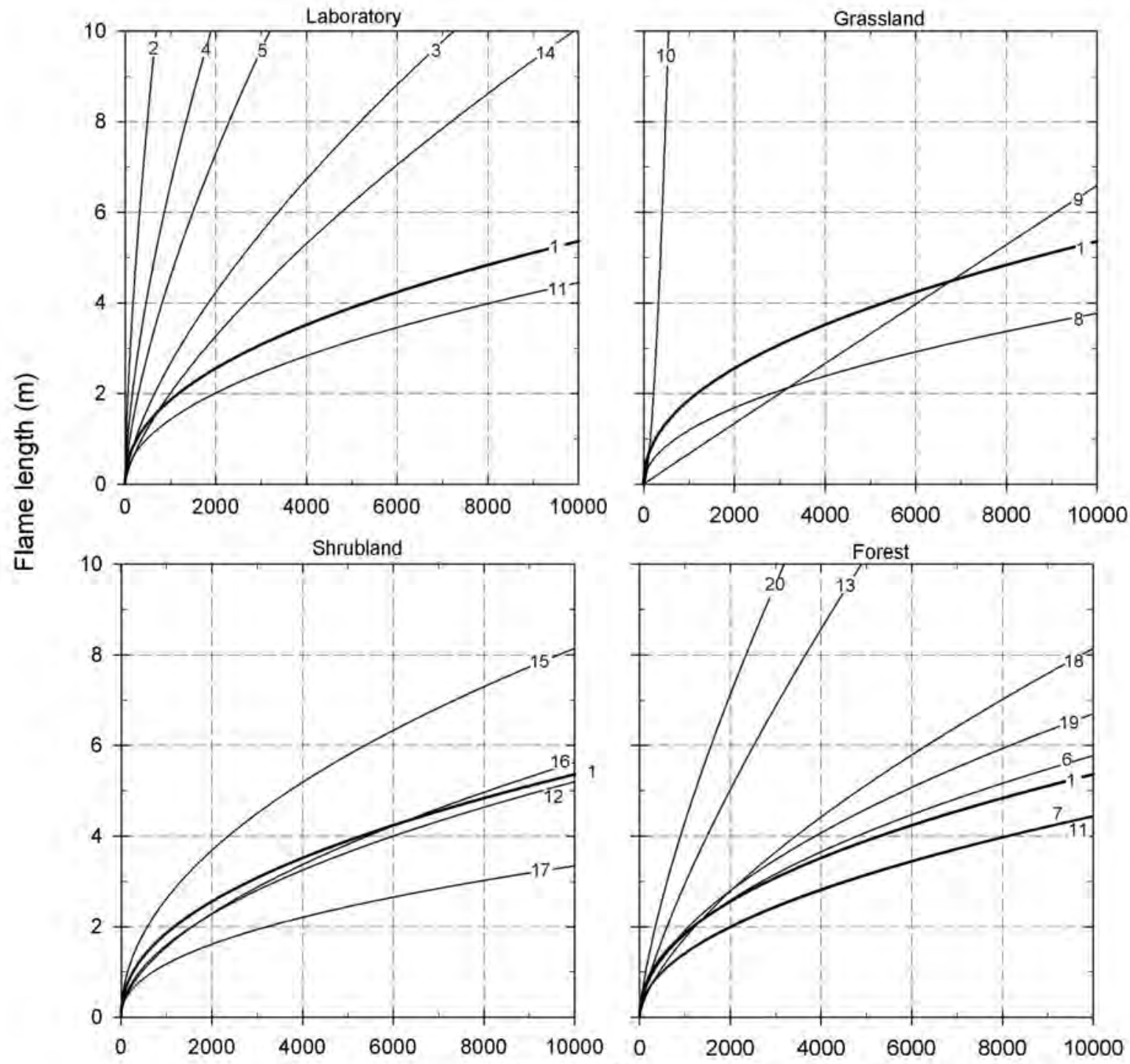

Fireline intensity $(\mathrm{kW} / \mathrm{m})$

Fig. 3. Graphical representation of Byram's (1959) flame length - fireline intensity relationship for pine litter with grass understorey (represented by curve $\mathbf{1}$ ) and other models (field and laboratory based) reported in the literature by four broad fuelbed types according to the listings given in Alexander and Cruz (2012b): $\mathbf{2}$ - wood cribs (Fons et al. 1963); $\mathbf{3}$ - wood cribs (Thomas 1963); 4 - lodgepole pine slash (Anderson et al. 1966); $\mathbf{5}$ - Douglas-fir slash (Anderson et al. 1966); $\mathbf{6}$ - general rule of thumb (Newman 1974); 7 - understory fuels (Nelson 1980); 8 - southern USA fuels (Nelson 1980); 9 - grasslands-head fire (Clark 1983); 10 - grasslands-backfire (Clark 1983); 11 - litter and shrubs (Nelson and Adkins 1986); 12 - fynbos shrublands (van Wilgen 1986); 13 - eucalypt forest (Burrows 1994); 14 - excelsior (Weise and Biging 1996); 15 - shrublands (Vega et al. 1998); 16 - shrublands (Catchpole et al. 1998); 17 - shrublands (Fernandes et al. 2000); 18 - 10-m tall jack pine forest-crown fire (Butler et al. 2004); 19 - maritime pinehead fire (Fernandes et al. 2009); and 20 - maritime pine-backfire (Fernandes et al. 2009). All of the relationships, unless otherwise specified, are for heading surface fires. The relationships represented by curves $\mathbf{7}$ and $\mathbf{1 1}$ are very similar but not truly identical.

from that equation list. The variation shown in Fig. 4 is a reflection of the tree species, stand structure and surface fuel characteristics as well as measurement methodologies (Alexander and Cruz 2012a). However, the levels of ambient air temperature and in-stand wind speed associated with the experimental fires involved in the model development can also have a significant influence (Alexander and Cruz 2012a).

\section{Fire Management Applications}

There will be occasions where there is a requirement to calculate $L$ from $I_{B}$, where $I_{B}$ is in turn provided for by some other model or system (e.g., Cruz et al. 2008, Wotton et al. 2009), for matters other than predicting crown fire initiation (Keyes and O'Hara 2002) or perhaps even crown scorch height (Norum 1977). For example, $L$ is a required input in comput- 

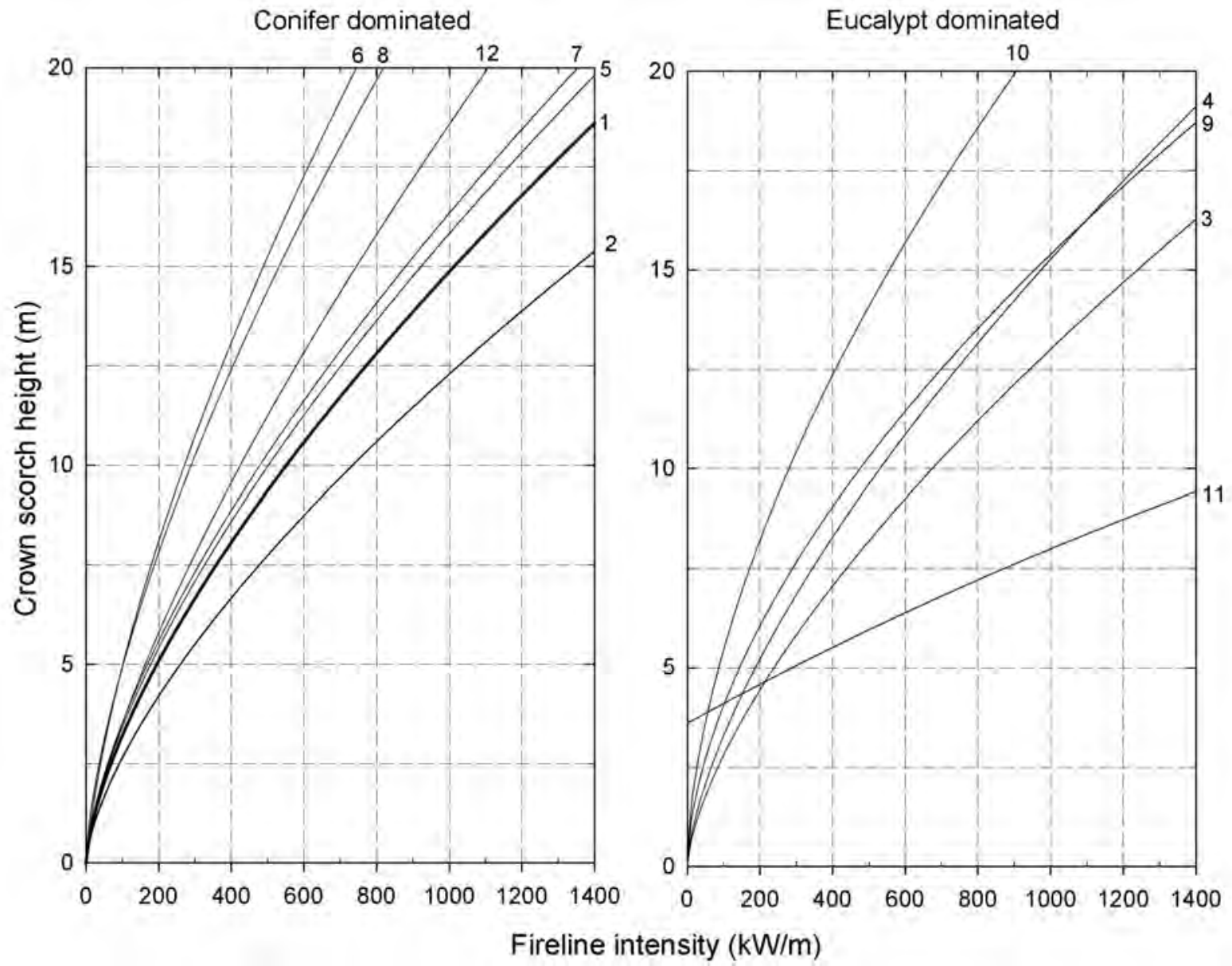

Fig. 4. Graphical representation of Van Wagner's (1973) fireline intensity - crown scorch height relationship for red pine-white pine-jack pine-northern red oak forests (represented by curve $\mathbf{1}$ ) and other models reported in the literature according to the listings given in Alexander and Cruz (2012a): 2 - slash and Caribbean pine (McArthur 1971 based on adaptation by Alexander 1998); 3 - eucalypt forest (Cheney 1978 based on adaptation by Alexander 1998); 4 - eucalypt forest (Luke and McArthur 1978 based on adaptation by Alexander 1998); 5 - radiata pine thinning slash (derived by Alexander 1998 based on data presented in Burrows et al. 1988); $\mathbf{6}$ - radiata pine wildings (Burrows et al. 1989); 7 - ponderosa pine (Saveland et al. 1990); 8 - coast redwood (Finney and Martin 1993); 9 - jarrah forest-spring (Burrows 1994); 10 - jarrah forest-summer (Burrows 1994); 11 - grassland-eucalypt savanna (Williams et al. 1998); and $\mathbf{1 2}$ - maritime pine (Fernandes 2002). All of the relationships are for heading surface fires.

ing maximum potential spotting distance in non-forested fuel types such as grass, shrubs and slash (Albini 1983, Morris 1987), in estimating the width of firebreak needed to stop a fire of a given intensity level in the absence of severe spotting (Byram 1959; Wilson 1988; Tymstra et al. 2010), in gauging firefighter safety zone size (Butler and Cohen 1998), and in judging an initial attack fire suppression effectiveness (Murphy et al. 1991, Hirsch et al. 1998).

Similarly, there could be a need to estimate $I_{B}$ from postburn observations or measurements of $h_{s}$ (Wilson and Ferguson 1986, Martinson and Omi 2008). As Agee (1993) notes, "It is often desirable to reconstruct fireline intensity in postfire monitoring to compare fire effects in different fires or different areas of a single fire."

Fig. 3 and Fig, 4 can be used jointly to help relate $h_{s}$ to $L$ in prescribed underburning (McRae et al. 1994). Regardless of the situation, fire management practitioners will find the graphical aids presented here (Fig. 3 and Fig. 4) a handy ref- erence to quickly visualizing the relationships between flame length and fireline intensity as well as crown scorch height in relation to fire intensity for a number of fuel complexes.

For many years now, equations [2] and [3] have been viewed as largely generic in nature (Alexander and Cruz 2012a). It should be clear from the graphical aids presented here that fuel complex structure needs to be considered in mathematical relationships involving fireline intensity and that the development of single, standardized $L-I_{B}$ and $I_{B}-h_{s}$ models is not possible. The graphs also give some sense of the variability that exists for broad fuel or vegetation types.

It is worth noting that all of the models displayed in Fig. 3 and Fig. 4 are for surface fires (Fig. 1) except for the crown fire $L-I_{B}$ model of Butler et al. (2004) where $L$ constitutes the free flame above the overstorey tree canopy (Fig. 2b). When this value is added to the average stand height it provides for an approximation of the height of the nearly vertical "wall of flame" typically associated with crown fires (Fig. 2b). 
While the present compilation of relationships represented by Fig. 3 and Fig. 4 cover a considerable range in vegetation and fuelbed characteristics, there are undoubtedly gaps in the coverage (e.g., masticated fuel treatments, blowdown, matted leaf litter) that presumably will be addressed by fire research in the future. In the meantime, how might one best go about selecting the most applicable $L-I_{B}$ model from the present list of 20 choices or the most appropriate $I_{B}-h_{s}$ model from the 12 different options?

In some cases, a good or fair match will readily exist. For example, maritime pine can be used for ponderosa pine or other long-needle pines. In other situations, judgement will be required based on comparisons to fuel properties like size, shape, texture, quantity, and arrangement, including the presence or absence of ladder fuels. This will require the user to consult the original source documents. In other cases the differences in $L$ or $h_{s}$ within a certain range of $I_{B}$ maybe inconsequential. Extrapolation between relationships will also undoubtedly be required in some instances. Comparisons between estimates of $I_{B}$ and observed $L$ or $h_{s}$ values may also prove useful. Rothermel (1991), for example, recommended using Thomas's (1963) model for predicting the flame length of crown fires based in part on general observations and subsequent comparisons.

\section{Acknowledgments}

This note is a contribution of Joint Fire Science Program Project JFSP 09-S-03-1. The comments of O.B. Armitage, A.P. Dimitrakopoulos, N.M. Vaillant, and R.H. Ziel, as well as K.K. Johnson and an anonymous reviewer on earlier drafts of this note are appreciated.

\section{References}

Agee, J.K. 1993. Fire ecology of Pacific Northwest forests. Island Press, Washington, DC. 493 p.

Albini, F.A. 1983. Potential spotting distance from wind-driven surface fires. USDA For. Serv., Intermt. For. Range Exp. Stn., Ogden, UT. Res. Pap. INT-309. 27 p.

Alexander, M.E. 1982. Calculating and interpreting forest fire intensities. Can. J. Bot. 60: 349-357.

Alexander, M.E. 1998. Crown fire thresholds in exotic pine plantations of Australasia. Aust. Natl. Univ., Canberra, ACT. Ph.D. Thesis $228 \mathrm{p}$.

Alexander, M.E. and M.G. Cruz. 2012a. Interdependencies between flame length and fireline intensity in predicting crown fire initiation and crown scorch height. Int. J. Wildland Fire 21: 95-113. Alexander, M.E. and M.G. Cruz. 2012b. Estimating flame length from fireline intensity [online]. Available from http://www.publish. csiro.au/?act=view_file\&file_id=WF11001_AC.pdf [Accessed 21 January 2012].

Anderson, H.E., A.P. Brackebusch, R.W. Mutch, and R.C. Rothermel. 1966. Mechanisms of fire spread research progress report no. 2. USDA For. Serv., Intermt. For. Range Exp. Stn., Ogden, UT. Res. Pap. INT-28. 29 p.

Beck, J., J. Parminter, M. Alexander, E. MacDermid, T. Van Nest, A. Beaver and S. Grimaldi. 2005. Fire ecology and management In S.B. Watts and L. Tolland (eds.). Forestry handbook of British Columbia. pp. 489-525. Univ. British Columbia, Fac. For., Vancouver, BC.

Burrows, N.D. 1994. Experimental development of a fire management model for jarrah (Eucalyptus marginata Donn ex Sm.) forest. Australian National University, Canberra, ACT. Ph.D. Thesis. 293 p. Burrows, N.D., R.H. Smith and A.D. Robinson. 1988. Prescribed burning slash fuels in Pinus radiata plantations in Western Australia. West. Aust. Dep. Conserv. Land Manage., Perth, WA. Tech. Rep. 20.12 p.
Burrows, N.D., Y.C. Woods, B.G. Ward and A.D. Robinson. 1989. Prescribing low intensity fire to kill wildings in Pinus radiata plantations in Western Australia. Aust. For. 52: 45-52.

Butler, B.W. and J.D. Cohen. 1998. Firefighter safety zones: how big is big enough? Fire Management Notes 58(1): 13-16.

Butler, B.W., M.A. Finney, P.L. Andrews and F.A. Albini. 2004. A radiation-driven model of crown fire spread. Can. J. For. Res. 34: 1588-1599.

Byram, G.M. 1958. Some basic thermal processes controlling the effects of fire on living vegetation. USDA For. Serv., Southeast. For. Exp. Stn., Asheville, NC. Res. Note 114. 2 p.

Byram, G.M. 1959. Combustion of forest fuels. In K.P. Davis (ed.). Forest fire: control and use. pp. 61-89, 554-555. McGraw Hill, New York, NY.

Catchpole, W.R., R.A. Bradstock, J. Choate, L.G. Fogarty, N. Gellie, G. McCarthy, W.L. McCaw, J.B. Marsden-Smedley and G. Pearce. 1998. Cooperative development of equations for heathland fire behaviour. In D.X. Viegas (ed.). Proceedings of 3rd International Conference on Forest Fire Research/14th Conference on Fire and Forest Meteorology, Volume II. pp. 631-635. Univ. Coimbra, Coimbra, Portugal.

Cheney, N.P. 1978. Guidelines for fire management on forested watersheds, based on Australian experience. In Special Readings in Conservation. pp. 1-37. Food Agric. Organ. United Nations, Rome, Italy. FAO Conserv. Guide 4.

Clark, R.G. 1983. Threshold requirements for fire spread in grassland fuels. PhD dissertation, Texas Tech University, Lubbock, TX. Ph.D. Diss. 72 p.

Cruz, M.G., M.E. Alexander and P.A.M. Fernandes. 2008. Development of a model system to predict wildfire behaviour in pine plantations. Aust. For. 71: 113-121.

Fernandes, P.M. 2002. Desenvolvimento de relacoes predictivas para uso no planeamento de fogo controlado em povoamentos de Pinus pinaster Ait. (Development of predictive relationships for use in planning prescribed fire in Pinus pinaster Ait. stands). Universidade de Tras os Montes e Alto Douro, Vilas Real, Portugal. PhD Thesis. 267 p. [In Portugese]

Fernandes, P.M., H.S. Botelho, F.C. Rego and C. Loureiro. 2009. Empirical modelling of surface fire behaviour in maritime pine stands. Int. J. Wildland Fire 18: 698-710.

Fernandes, P.M., W.R. Catchpole and F.C. Rego. 2000. Shrubland fire behaviour modelling with microplot data. Can. J. For. Res. 30: 889-899.

Finney, M.A. and R.E. Martin. 1993. Modeling effects of prescribed fire on young-growth coast redwood trees. Can. J. For. Res. 23: 1125-1135.

Fons, W.L., H.B. Clements and P.M. George. 1963. Scale effects on propagation rate of laboratory crib fires. Symp. (Int.) Combust. 9: 860-866.

Hirsch, K.G., P.N. Corey and D.L. Martell. 1998. Using expert judgment to model initial attack fire crew effectiveness. For. Sci.44: 539-549.

Keyes, C.R. and K.L. O'Hara. 2002. Quantifying stand targets for silvicultural prevention of crown fires. West. J. Appl. For. 17: 101-109.

Luke, R.H. and A.G. McArthur. 1978. Bushfires in Australia. Aust. Govt. Publ. Serv., Canberra, ACT. 359 p.

McArthur, A.G. 1971. Aspects of fire control in the P. caribaea \& P. elliottii plantations of northwestern Viti Levu, Fiji Islands. Commonw. Aust., For. Timber Bureau, For. Res. Instit., Canberra, ACT. $52 \mathrm{p}$.

McRae, D.J., T.J. Lynham and R.J. Frech. 1994. Understory prescribed burning in red pine and white pine. For. Chron. 70: 395-401. Morris, G.A., Jr. 1987. A simple method for computing spotting distances from wind-driven surface fires. USDA For. Serv., Intermt. For. Range Exp. Stn., Ogden, UT. Res. Note INT-374. 6 p.

Murphy, P.J., P.M. Woodard, D. Quintilio and S.J. Titus 1991. Exploratory analysis of the variables affecting initial attack hot-spotting containment rate. Can. J. For. Res. 21: 540-544. 
Nelson, R.M., Jr. 1980. Flame characteristics for fires in southern fuels. USDA For. Serv., Southeast. For. Exp. Stn., Asheville, NC. Res. Pap. SE-205. 14 p.

Nelson, R.M., Jr. and C.W. Adkins. 1986. Flame characteristics of wind-driven surface fires. Can. J. For. Res. 16: 1293-1300.

Newman, M. 1974. Toward a common language for aerial delivery mechanics. Fire Manage. Notes 35(1): 18-19.

Norum, R.A. 1977. Preliminary guidelines for prescribed burning under standing timber in western larch/Douglas-fir forests. USDA For. Serv., Intermt. For. Range Exp. Stn., Ogden, UT. Res. Note INT229. $15 \mathrm{p}$.

Rothermel, R.C. 1991. Predicting behavior and size of crown fires in the Northern Rocky Mountains. USDA For. Serv., Intermt. Res. Stn., Ogden, UT. Res. Pap. INT-438. 46 p.

Saveland, J.M., S.R. Bakken and L.F. Neuenschwander. 1990. Predicting mortality and scorch height from prescribed burning for ponderosa pine in northern Idaho. Univ. Idaho, Coll. For., Wildlife Range Sci., Idaho For., Wildlife Range Exp. Stn., Moscow, ID. Stn. Bull. 53.9 p.

Thomas, P.H. 1963. The size of flames from natural fires. Symp. (Int.) Combust. 9: 844-859.

Tymstra, C., R.W. Bryce, B.M. Wotton, S.W. Taylor and O.B. Armitage. 2010. Development and structure of Prometheus: the Canadian Wildland Fire Growth Simulation Model. Can. For. Serv., North. For. Cent., Edmonton, AB. Inf. Rep. NOR-X-417. 88 p.
Van Wagner, C.E. 1973. Height of crown scorch in forest fires. Can. J. For. Res. 3: 373-378.

van Wilgen, B.W. 1986. A simple relationship for estimating the intensity of fires in natural vegetation. South Afr. J. Bot. 52: 384-385. Vega, J.A., P. Cuinas, T. Fonturbel, P. Perez-Gorostiaga and C. Fernandez. 1998. Predicting fire behaviour in Galician (NW Spain) shrubland fuel complexes. In D.X. Viegas (ed.). Proceedings of 3rd International Conference on Forest Fire Research/14th Conference on Fire and Forest Meteorology, Volume II. pp. 713-728. Univ. Coimbra, Coimbra, Portugal.

Weise, D.R. and G.S. Biging. 1996. Effects of wind velocity and slope on flame properties. Can. J. For. Res. 26: 1849-1858.

Williams, R.J., A.M. Gill and PHR Moore. 1998. Seasonal changes in fire behaviour in a tropical savanna in Northern Australia. Int. J. Wildland Fire 8: 227-239.

Wilson, A.A.G. 1988. Width of firebreak that is necessary to stop grass fires: some field experiments. Can. J. For. Res. 18: 682-687.

Wilson, A.A.G. and I.S. Ferguson. 1986. Predicting the probability of house survival during bushfires. J. Environ. Manage. 23: 259-270. Wotton, B.M., M.E. Alexander and S.W. Taylor. 2009. Updates and revisions to the 1992 Canadian Forest Fire Behavior Prediction System. Can. For. Serv., Great Lakes For. Cent., Sault Ste. Marie, ON. Inf. Rep. GLC-X-10. 45 p. 